\title{
BORDER IMPERIALISM AND EXCLUSION IN CANADIAN PARLIAMENTARY TALK ABOUT INTERNATIONAL STUDENTS
}

\author{
DALE M. MCCARTNEY \\ UNIVERSITY OF THE FRASER VALLEY
}

\begin{abstract}
Although there is a rich critical literature examining international student policy in Canada, very little of it considers the views of Members of Parliament. MPs have limited direct influence over international student policy, but their policy talk about international students defines the context within which such policy is developed. For that reason Parliamentary debate deserves study. This paper examines MPs' discussion of international students between 1984 and 2019, tracing themes in MP policy talk over the globalization era. It finds that MPs evince remarkably consistent attitudes towards international students. Throughout the period MP policy talk shows that Parliamentarians saw international students as outsiders who were only of value to the extent that they could be made to serve Canada's economic or political agenda. The uniformity of this attitude and the lack of dissenting voices suggest that MPs' views may be a significant barrier to reforming international student policy in Canada.
\end{abstract}

Keywords: international students, Parliament of Canada, international education policy, border imperialism, migrants

\section{Résumé}

Bien qu'il existe une riche littérature critique sur la politique relative aux étudiants étrangers au Canada, très peu d'études se penchent sur les opinions des députés à ce sujet. L'influence directe de ces derniers en cette matière est limitée, mais leurs discussions définissent le contexte dans lequel cette politique est élaborée. Pour cette raison, les débats parlementaires méritent d'être étudiés. Le présent article examine les discussions des députés au sujet des étudiants étrangers entre 1984 et 2019. Ce faisant, il retrace les thèmes qui les ont traversées à travers l'époque de la mondialisation. II en ressort que les députés font montre d'une attitude remarquablement cohérente en ce qui a trait aux étudiants étrangers. Sur toute la période, ces discussions démontrent que les parlementaires ne considèrent la valeur des étudiants étrangers que dans la mesure où ils peuvent servir le programme économique ou politique du Canada. La constance de cette attitude et l'absence de voix dissidentes suggèrent que les opinions des députés pourraient constituer un obstacle important à une réforme des politiques relatives aux étudiants étrangers au Canada.

Mots-clés : étudiants étrangers, Parlement du Canada, politique d'éducation internationale, impérialisme frontalier, migrants

\section{Introduction}

While there is a rich critical literature examining international student policy in Canada (e.g., Beck, 2012; Johnstone \& Lee, 2014, 2017 ; Stein, 2017b; Trilokekar \& El Masri, 2016), very little of it considers the views of Members of Parliament (MPs). This is not especially surprising given MPs are not that central to the policy making process regarding international students. Traditionally education policy in Canada is a Provincial responsibility, which means the Federal Parliament has limited jurisdiction; moreover, the connection between Parliamentary discussion-especially by opposition MPs—and actual policy production is somewhat tenuous. Nonetheless, parliamentary discussions are important because they speak to the broader political discourse within which international student policy is created. This is compounded by the role the Federal government plays in governing 
international students as (im)migrants (Brunner, 2017), and by the creation of a Federal international education strategy in 2014 (Government of Canada, 2014).

Despite their limited direct impact on international student policy, MPs are influential figures whose attitudes deserve study. Debate in the House of Commons is a particularly important form of what American educational historians David Tyack and Larry Cuban call policy talk, the "diagnoses of problems and advocacy of solutions" (Tyack \& Cuban, 1995, p. 40) that characterize public discussion of educational policy. They distinguish it from the policy action through which the policy talk is implemented, and suggest that while policy talk is often cyclical and can shift directions "at a dizzying pace," policy action is much "slower and more complex" to change (Tyack \& Cuban, 1995, pp. 40-41). Policy talk does not immediately dictate the content of policy, but it does shape the context within which policy action takes place. When MPs debate about international students, they set out the boundaries within which a policy will appear rational and democratically legitimate. Although MPs' discussion of international students does not translate directly to the policies enacted at even the Federal lev$\mathrm{el}$, the assumptions and underlying attitudes that shape their policy talk help to define the limits of policy action.

MPs' role in policy talk makes their discussion of international students important, even more so for any attempt to make international student policy more just, or more sustainable. Sharon Stein's work mapping attitudes toward internationalization among scholars demonstrates that there is important new scholarship over the past half-decade advocating for reforms or even radical changes to internationalization of education and international student policy (Stein, 2017a). Organizations like the Association of Canadian Deans of Education and the Canadian Bureau for International Education have also published reports relatively recently setting out ethical best practices for internationalization, suggesting they too see a need to reform the internationalization process (Association of Canadian Deans of Education, 2014; Canadian Bureau for International Education, 2014). And there is an emerging literature examining internationalization through the lens of sustainability (in which this special issue is situated) that offers a new angle for the potential reform of international engagement by post-secondary institutions (e.g., Chen \& Chen, 2018; Hudzik, 2014; llieva et al., 2014; Jang, 2017). The proliferation of these perspectives suggests we are in a historical moment when important reforms to internationalization strategies may be possible; however, for those who desire these sorts of reforms, a cleareyed analysis of the challenges faced is necessary. This paper attempts to contribute to this analysis by examining one element of the context in which these calls for reform are emerging, and with which any serious attempts to change the direction of internationalization will have to grapple-the perspective of Members of Parliament.

In examining the discussion of international students in the House of Commons, it becomes clear very quickly that MPs have few concerns about the justice of international student policies, and no desire for reform of those policies. MPs persistently discuss international students as outsiders and as vehicles for Canada's economic and foreign policy goals and use them to delineate and police the boundaries of the idea of the Canadian nation. Even when new policy initiatives emerged, such as the introduction of immigration pathways for international students, MPs' attitudes toward students remained fundamentally unchanged. This paper draws out these themes in MPs' policy talk to warn that contemporary efforts to make international student policy more just and equitable face a considerable barrier in the attitudes of Canadian MPs.

\section{Theoretical Framework}

To make sense of MP policy talk about international students, it must be situated within the historical context of contestation over access to resources, especially access to educational places, economic opportunity, and Canadian citizenship. Much of this contestation revolves around the notion of a border in Canada, and who is deserving of the benefits of Canadian education and-after the 1990s-potential for Canadian citizenship (Brunner, 2017). Therefore, this essay draws on the rich theoretical literature examining the notions of citizenship and belonging in Canada, particularly the work of Himani Bannerji $(1995,1996,2000)$, Nandita Sharma (2006), and Harsha Walia (2013). Although there are important tensions in their work, for the purposes of this paper, they serve as guides to explain the context in which the comments of MPs arrive. Bannerji $(1995,2000)$ explains how discussions of new arrivals to Canada are always shaped by ideological notions of who belongs in Canada, and who has a right to its resources. Sharma (2006) shows 
that these notions are codified into policy categories such as migrants and thereby made to appear to be legitimate legal frameworks. And Walia (2013) demonstrates that these distinctions and categories are meant to serve Canada's larger interests as a settler-colonial imperial power attempting to "secure land and resources for state and capitalist interests" (p. 37). Members of Parliament's discussion of international students reproduces these ideological barriers between citizen and non-citizen, deserving and non-deserving, beneficiary of international education and payer for international education.

\section{Methods}

This paper is a work of critical policy analysis. It employs a historical method (Brewer, 2014; Gale, 2001) to examine Member of Parliament discussion of international students in the late Cold War and globalization eras, from the formation of Brian Mulroney's Progressive-Conservative government in 1984 to the end of Justin Trudeau's Liberal government's first parliament in 2019. It draws on the emerging methodology of the "history of the present" (Kleinberg et al., 2020) to examine historical records through theoretical frames, in order to surface the unspoken assumptions and ideologies driving international student policy talk. To do this, I used the Linked Parliamentary Data project from the University of Toronto (Beelen et al., 2017) to scrutinize all statements made in the House of Commons between 1984 and 2019 about international student(s), foreign student(s), and visa student(s). In total, there were 156 references to international student(s), 143 to foreign student(s), and nine to visa student(s). Some of these were repeats or used the phrase in a context that was not relevant. After discarding these results, there was a total of 274 unique comments made in Parliament and captured by Hansard about international students. Once they were identified, each statement was analyzed within its specific context, such as the parliamentary debate within which it took place and the political party of the speaker, but also in the broader context of ideologies of (im)migration and the construction of a Canadian nation (Bannerji, 2000; Sharma, 2006; Walia, 2013). While recognizing the role of the researcher in interpreting evidence, patterns were allowed to emerge inductively from the examination of the comments themselves. Though I examined the Parliamentary records with a critical consciousness about the Canadian national project, I tried to grapple with
MPs' viewpoints by taking their words seriously. In an attempt to relay this method and justify my findings, I have included extensive quotations throughout the article.

Methodological discussions of critical policy analysis "often include a nod toward the importance of historicizing" because the "the practices of problem definition and policy-making" can only be fully examined "through a detailed portrait of the sociohistorical context" (Brewer, 2014, p. 273). Historical methods are key to this examination. Critical policy analysis has several potential goals, but one is to seek to explain how policy "emerged, what problems it was intended to solve, how it changes and developed over time, and its role in reinforcing the dominant culture" (Diem et al., p. 1072). This essay, in focusing on policy talk, situates the framing of international student policy in Canada within the larger historical process of immigration, citizenship, and the construction of a national ideology. Often, historical analysis traces change over time, but this essay finds that there was remarkable consistency in MP policy talk. Thus, it tries to explain how, even as the historical context changed dramatically around it, the themes in policy talk about international students remained essentially unchanged.

\section{MP Policy Talk in the Era of Globalization}

The end of the Cold War in the late 1980s and early 1990 s brought about vast political changes. In the period covered by this paper the Berlin Wall was torn down and the Soviet Union collapsed; the world wide web was invented and popularized; Canada signed the North American Free Trade Agreement and dramatically reduced corporate taxes, launching the era of globalization (McBride, 2005; Teeple, 2000); 9/11 marked the beginning of the War on Terror, and Canada invaded Afghanistan, occupying it for 13 years. This period included the introduction of both internationalization (Knight, 2015)-a process that has greatly expanded the scale of international student mobility-and neoliberalism, which has deeply impacted economic, political, and social policies (Brownlee et al., 2018; Harvey, 2005; McBride, 2005). At a partisan level, the changes have been almost as enormous. Over this time Canada has had six governments and 10 Parliaments. MPs from six different parties (and one independent) discussed international students in some capacity. These discussions began before dif- 
ferential fees had been introduced in all provinces and before international students had a pathway to immigration. In 1986-1987 there were only 27,655 international students in Canada (Holdaway et al., 1988); in 2018 there were 572,415 (Canadian Bureau for International Education, 2019).

Yet despite all of these changes, throughout this period MP policy talk about international students remained remarkably coherent, with consistent themes that went unchallenged during the entire period. Across party, across government, and throughout the 35-year time period, MPs consistently demonstrated the same assumptions about international students when they talked about them. Bannerji alerts us that when perspectives become common sense, they can more easily serve to perpetuate racist and colonial social orders, as they operate at a level that makes them difficult to interrogate (Bannerji, 1995). In the uniformity of MP policy talk we can see the power of common sense notions, and the ways in which, in this specific case, those notions demarcate international students as outsiders who had no claim to Canadian resources, even after Canada created a pathway for students who had finished their studies to become citizens. The very fact that the shifting context within which policy talk was occurring did not substantially change these attitudes highlights how naturalized they have become, resulting in them being the invisible, unspoken boundaries that confine the construction of international student policy.

My examination of MPs' policy talk revealed two themes in their discussions of international students: an unshakeable confidence in the self-evident quality of Canadian higher education and the corresponding belief that therefore international students were lucky to have access to it-a colonial concept that has deep roots in western education (Abdi, 2012; Angulo, 2012; Coloma, 2009; Willinsky, 1998); and a constant insistence that international students should only be welcomed in Canadian institutions as long as they could provide a measurable benefit to the Canadian economy in the short and longer term-a concept that is embedded within a Canada-first attitude woven into the history of Canadian immigration policy. These themes are continuations of the longstanding themes in policy talk about students, with some small adjustments for the changing times and context. While there was one MP that resisted these themes, their overall consistency and the way in which they are stated as obvious and taken for granted by the rest of Parliament means they define the contours of all policy talk about international students throughout the era of globalization.

\section{Theme One: The Quality of Canadian Higher Education}

Throughout the 35 years of discussion, MPs frequently (and with great relish) commented upon their perception of the quality of Canadian post-secondary education. MPs congratulated Canada for its "illustrious institutions" (Epp, 1994), and argued that Canadian "universities stand in their excellence, par excellence, second to none" (Malone, 1990). Canada offered "world-class" schools that "have a stellar history and reputation for recruiting high-calibre students to our community" (DeCourcey, 2016a). These kinds of comments are common in Parliamentary policy talk about international students-there were 34 mentions of international students that included some discussion of the quality of Canadian higher education, meaning more than $12 \%$ of the time MPs were discussing international students they felt it necessary to mention the status of Canadian institutions. In fact, MPs occasionally used international students themselves to prove the quality of Canadian institutions. When an opposing member (without mentioning international students) suggested that Canadian schools might not be of the same standard as American or British universities, Progressive-Conservative (PC) MP Arnold Malone angrily insisted that "foreign students coming to Canada will claim that part of the reason they come here" is the quality of the universities, and demanded that his Liberal opponent show "empirical evidence" to support the "unsubstantiated" claim that Canadian post-secondary education trailed behind (Malone, 1990). These kinds of comments stem from-and serve to reproduce-longstanding colonial notions of western educational supremacy, and in the process they assert a coherent Canadian state that is the inheritor of this violent lineage. As Bannerji puts it, when Canada is described in these ways "a thinly veiled, older colonial discourse of civilization and savagery peeps out" (Bannerji, 2000, p. 107).

MPs' assertions of the quality of Canadian education were often made as part of the debate about what kinds of access international students should have to Canada. For some, like Liberal Matt DeCourcey, having "world- 
class universities" (2016b) meant there would be a great draw for international students, some of whom would wish to stay in Canada after their studies "and continue to contribute to [Canada's] socioeconomic wealth" (DeCourcey, 2016b). Quality of institution, the access that fee-paying international students deserved, and the benefits of their presence in Canada were all bound up in DeCourcey's analysis, and led him to advocate for creating policies that welcomed more international students for longer.

Others saw the quality of Canadian education and the opportunities it provided as something to hoard, or at least to portion out very selectively. DeCourcey argued that the quality of the schools meant they were inevitably going to have a large number of international students, and that this was to Canada's benefit. Conservatives such as Chris Alexander felt that quality of Canadian education was a factor (Alexander, 2015), but that international students were primarily drawn to Canada because that education provided considerable economic opportunities within Canada (Alexander, 2014). In his analysis, economic and educational opportunities needed to be portioned out carefully, and while his government worked to drastically increase the number of international students in Canada, he promised that the Conservatives were "doing everything in our power...to ensure young Canadians get first crack at today's opportunities" (Alexander, 2015). For both the Liberals and the Conservatives the quality of Canadian institutions was obvious but was to be used for different ends. Regardless of whether they were to be welcomed or limited, MPs used the idea of international students as a "categorical form of difference" that served to demarcate the limits of the Canadian state (Bannerji, 2000, p. 104). In the process such policy talk produces the assumption that Canada is "a singular entity" (Bannerji, 2000, p. 104), and in turn that international students are outside that entity, and have no reasonable claim to access to it, even if they intend ultimately to become citizens.

Because MPs saw Canadian higher education as being of such superlative quality, they felt that the students who attended the schools must similarly be exceptional. Thus, they insisted that Canada should focus on recruiting students they perceived to be the best and brightest to Canada's so-called world-class institutions. The pinnacle of this thinking was embedded in discussion of the creation of Canada's EduCanada branding strategy to attract international students in 2016 (Johnstone \& Lee, 2017; Stein, 2017b). As Chrystia Freeland, the Liberal Minister of International Trade who launched the strategy, put it in the House of Commons, the purpose of EduCanada was to "market the quality of a Canadian education" as a part of "promoting the Canadian brand abroad" (Freeland, 2016). Because of the quality of Canadian education and of the Canadian brand more broadly, Freeland remarked that Canada was targeting the "brightest international students" to enter its schools (Freeland, 2016). These kinds of ideas are codified throughout the government's international education policy materials (e.g., Government of Canada, 2014), and they circulate in policy talk as well.

An important corollary of the idea of Canadian schools being of especially high quality is the assumption that exposure to them would serve to help "develop" the home countries of international students, after they left Canada when their studies were finished. This was a very common idea in Cold War era policy talk (McCartney, 2016), and appeared in 21 (7.6\%) of the comments discussed here. Generally the comments are asides: for example, when the PC government founded the Asia-Pacific Foundation of Canada in 1984, the Deputy Prime Minister and Secretary of State for External Affairs suggested in passing that hosting international students was an indirect continuation of the work Canada had begun under the Colombo Plan, an aid agreement established in 1950 (Pepin, 1984). Twenty years later a Liberal Minister of Citizenship and Immigration, Denis Coderre, would make a similar comment, arguing that international students "are truly an investment, not only for us, but for the country of origin" (Coderre, 2003). For some MPs this was not a passing advantage but was the reason to bring these students to Canada. Joe Clark, for example, the PC Secretary of State for Foreign Affairs in 1986, suggested that international students were "an important asset" for "developing countries" (Clark, 1986), and thus encouraged the government to expand the number of scholarships it offered international students, and to make more spaces for them in Canadian schools. Liberal MP Ben Serré encouraged Canada to use aid funding to increase the number of international students in Canada because attending a Canadian university "would enable foreign students to return to their homeland with the ability to feed their own people" (Serré, 1994). Although these kinds of comments are less 
common than blanket statements about the high quality of Canada's universities, they stem from the same confidence in Canadian education and the same colonial attitudes (Bannerji, 2000). Moreover, they demonstrate that for some MPs this confidence meant they felt international students trained in Canadian universities could, by dint of this superior education, help their home countries develop.

There are two standout takeaways from the broad agreement among MPs about the quality of Canadian education. The first is the obvious, but still important, point that this is evidence of a deeply western-centric view of education. The fact that the claim that Canadian schools went unchallenged, and the corresponding implication that international students came to Canadian schools because those schools were better than those at home, is evidence of "western dominance in the global knowledge economy era" (Johnstone \& Lee, 2017, p. 1075). There is a straight line to be traced from Cold War era claims of Canadian educational superiority to the assumptions underpinning the EduCanada strategy. For many MPs, this perspective still includes the assumption that exposure to Canada's superior education system would inevitably benefit international students' underdeveloped home countries, an attitude that entirely disregards the possibility of other knowledges. As Robert Aman puts it, "the hierarchies instilled by imperialism disqualified the colonised populations...from being capable of intellectual labour" in the eyes of the colonizers, and in the eyes of many contemporary MPs (Aman, 2018, p. 16).

The perception that Canadian education was of unique-and heavily sought-after-quality also contributed to the belief that access to it should be portioned carefully, to those who deserved access. In policy talk the notion of deserving access was frequently framed as an issue of merit (it should go to the best and the brightest), while in practical terms it was also an issue of financial power (it would go to those who could muster a reasonable academic performance and could afford the ever-growing tuition fees). These delineations of deserving and undeserving also serve to demarcate the borders of the idea of the nation (Bannerji, 1996, 2000). Whether they felt (as many Liberals did) that access should be shared widely or (as many Conservatives seemed to) that it should be offered more narrowly, everyone agreed that the special quality of Canadian education meant that only students who could reach a certain threshold deserved to enter. This creates a "cat- egory of otherness" that serves to "delimit the membership of this nation and this state" and is evidence that there is a "crisis in citizenship and a continual attempt to manage this crisis" (Bannerji, 2000, p. 66). In managing this crisis, it becomes important to situate education as a desirable privilege of citizenship, to which access is limited. For Bannerji, this is the process of making Canada as a nation-it reaffirms the in-group by defining those who are excluded, and encourages both groups to see what might be considered their rights (that is, public education) to be a privilege for which they must either be grateful, or audition to prove their worthiness.

\section{Theme Two: International Students as Vehicles for Canadian Policy Goals}

Throughout the history of Canadian (im)migration policy, as Robert Harney explained more than 30 years ago, the perspective of the government has been that "the migration phenomenon exists to serve the host country, not the migrants, and that not only the flow of immigration but its sources and character are matters that Canadian authorities can and should manipulate" (Harney, 1988, p. 53). Thus, it is unsurprising that Parliamentary discussion of international students would often revolve around how those students might serve to advance Canada's interests. This is the defining theme of policy talk about international students, as some version of it appears in 187 of the comments made by MPs about international students, or $68 \%$ of all references to them in Hansard. MPs argued that international students were important to Canada's domestic economy; that they were valuable as vehicles for Canadian foreign policy goals; that they contributed to Canada as temporary workers, filling jobs $\mathrm{Ca}-$ nadians were not willing to do; that they could help make domestic students more cosmopolitan, making it easier for them to work in the global economy; and-since the early 2000 s-that international students were potentially valuable as immigrants, as their education would ensure they were already assimilated to Canadian life. This final element of MP policy talk is a recent addition, but it is not a significant break with existing themes. Although international students now have a pathway to permanent residency that did not exist in the past (Brunner, 2017), MP policy talk still evaluated them in relation to their value to Canada. 
In contrast to the persistence of themes of Canadian self-interest in MP policy talk, there was almost no recognition that international students might offer valuable alternative views of the world, or that they might have intellectual contributions to make to post-secondary institutions. Although MPs often suggested there were social and educational benefits to having international students on Canadian campuses, when these benefits were articulated they, with one exception, framed international students as useful for making Canadians more cosmopolitan. Ultimately international students are framed within the policy talk of MPs almost entirely through the question: What can they offer to Canada?

Depicting international students as valuable only in the ways that they could advance Canadian policy goals is both the product of, and serves to reinforce, two interlocking exclusionary mechanisms percolating throughout policy talk about international students. The first is border imperialism, the process by which borders-both geographical and in citizenship-are used to police who is to be included within the nation-state (Walia, 2013). Canadian MP discussion of international students revolves around the value of students to Canada because of the implicit assumption that only those people who advance Canada's goals are entitled to the privilege of entry to the country and its higher education institutions. This notion depends upon, and reinforces, the power of the border as an ideological division between those who have a right to the resources of the nation-state and those who must prove their worthiness.

Border imperialism is legitimized by its incorporation into legal frameworks of citizenship and migrancy. The construction of migrancy as a category of non-citizenship occurred in Canada over the decades after the Second World War but was formalized in the 1970s with the reform of the Immigration Act 1976 (Sharma, 2006). This process relied upon "the construction of a zero-sum game between Us-Canadians and those rendered as the foreign-Other" which served to "abstract or objectify the ongoing reproduction of ruling relations" (p. 79). These ruling relations "of racism, imperialism, and patriarchy shaped how differently categorized people were socially and legally positioned both within and outside Canadian society" ( $p .75)$. The creation of "migrants" allowed the treatment of people so categorized to be "naturalized and, therefore, depoliticized" (p. 75). Policy talk about international students is informed by this framework, and serves to shore it up and normalize it, presenting an enormous challenge to those who wish to reform international student policy in Canada.

MPs were careful to reinforce international students' status as a type of migrant, frequently referencing them as likely to return home after their studies (e.g., Benoit, 2000; Folco, 2006; Marchi, 1987; Minna, 2008; Price, 2000). In one case, Liberal MP Maria Minna angrily denounced the Conservative government for calling international students new Canadians. As she said, international students are "not new Canadians. They are not here to stay" (Minna, 2008). Given MPs' insistence that international students are outsiders, it seems only natural and normal that MPs ignore their interests or intrinsic value as students and thinkers, and instead examine them solely on the basis of their value to the Canadian national project. MPs, for both partisan and likely personal reasons, did not always agree about the nature of that project or the direction it should take. But they all accepted the underlying notion that international students were outsiders who were there to serve the political goals of Canada at any given moment.

The most obvious evidence of this is in the regular exhortation that international students were economically beneficial for Canada. Since the 1980s MPs have consistently argued that international students benefit Canada's economy. Interestingly, they rarely mention tuition. Much more common is a discussion of the value of international students as consumers while studying in Canada. As early as 1987 Liberal MP Bill Rompkey called for the Conservative government to develop policies that would "provide greater access by international students to Canadian post-secondary institutions" (Rompkey, 1987), in part because they would "give an immediate infusion [of cash] into the Canadian economy," possibly as much as $\$ 600-700$ million a year (Rompkey, 1987). Rompkey felt so strongly about this he recommended the Federal government "take unilateral action now to provide to the provinces additional funding tied to the elimination of differential fees," because the fees were a barrier to enrolments and the overall value of international students far outweighed what was being gained from higher tuition (Rompkey, 1987).

The attitude that international students were valuable as consumers remained common well into the 21st century. Rahim Jaffer, a Conservative MP, told the House in 2006 that international students "bring about $\$ 4$ billion 
worth of investment into Canada every year by attending classes, taking up housing, and spending money when they come here to pursue their studies" (Jaffer, 2006). Less than a decade later Chungsen Leung, another member of the Conservative government, announced that "international students contribute over $\$ 8$ billion to the Canadian economy and $\$ 445$ million to government tax revenues each year, supporting more than 86,000 jobs" (Leung, 2013). By 2019, the "economic spinoffs" provided by international students were "worth about $\$ 15$ billion annually" (Hussen, 2019). Just as was true for Rompkey 30 years earlier, Canada's government in 2019 was working to make sure "international students are welcome in Canada" (Hussen, 2019) because they represented a substantial infusion of cash to the Canadian economy. In this way MPs framed international student recruitment as one part of an imperialist infrastructure that takes advantage of the global competition for economic opportunities to funnel wealth into the Canadian economy (Walia, 2013).

It was not just their spending in Canada that made international students valuable economically in the eyes of MPs. There was also a widespread belief that they would contribute to the long-term growth of the Canadian economy. Often this was through trade. Liberal MP Sergio Marchi assured the House in 1987 that hosting international students was valuable because:

many reports show that those people, when they go back to their own country, become ambassadors for Canada. If one of those foreign students ends up as the marketing director of a company in his own country, then you can bet your bottom dollar that Canada will be one of his markets. (Marchi, 1987)

Importantly, no MP ever offered any evidence that this would actually happen. Instead, this narrative rested on the assumption that the experience of studying in Canada would inevitably be positive given the MPs' perception of the quality of Canadian schooling.

Usually MPs were less specific about exactly how international students would benefit the Canadian economy, but nonetheless insisted that international students were a key to Canada's future in an emerging global economic order. Some saw this in building relationships with other countries, through bilateral relationships established and nourished by the presence of international students from the partner country in Canada (e.g., Can- nan, 2014; Coderre, 2002; Ludwig, 2017; Peschisolido, 2003; Saxton, 2012). As Liberal MP Denis Coderre put it in 2002, "We must focus our attention on foreign students. The foreign student is clearly the cement between the bilateral and the multilateral approach between countries" (Coderre, 2002). Frequently (as is certainly true of Coderre), MPs never specify the exact role they expect international students to play in a globalized economic future, but nonetheless they regularly point to that future to indicate the need for international students on Canadian campuses. Viewed through the lens of Canada's border imperialism, MPs' insistence that international students embody an unnamed but urgent element of Canada's economic future is an example of the ways in which the state "is evolving to continue to meet the needs of capitalist expansion through more flexible means of governance and accumulation" (Walia, 2013, p. 40)

MPs praised international students as consumers, and they celebrated them as a key component of Canada's economic future. Some also saw them as potentially valuable as a type of migrant workers during their studies. Conservative Rahim Jaffer, for example, praised his government for allowing international students to work in 2006 because, "as a small business person in the service industry," he knew that there was a "labour crunch" (Jaffer, 2006) across the country. Allowing international students to work would "help fill the gaps that we currently have in the employment market when it comes to the service industry" (Jaffer, 2006). Jaffer's colleague Ed Komarnicki called allowing international students to work a "visionary move" because it would, when coupled with "processing a record number of temporary foreign worker applications...meet the labour needs that have been experienced in our country" (Komarnicki, 2007). Although they faced some criticism (Telegdi, 2008), MPs, especially (though not exclusively) members of the Conservative Party, returned to this theme on occasion in the years after 2006 (e.g., Alexander, 2014; Clarke, 2018; Kang, 2019; Kenney, 2012). Although it received much less attention than the idea that international students were key to Canada's future economy, the idea that international students were valuable as migrant labourers is one more example of the Canada-centric views of MPs. It is also further evidence of the power of border imperialism to define the types of access that MPs felt students were allowed to have to Canada, and the ways in which the interests of Canada drove discussion of students in the House (Walia, 2013). 
Similarly, there are many passing references to the cultural, social, or educational value of including international students in Canadian institutions. These might have represented an opportunity for MPs to reflect on the intellectual and scholastic contributions of international students to education in Canada. But again, rather than appreciated on their own merits, international students are instrumentalized in these discussions as agents to change Canadians into more cosmopolitan and worldly thinkers, largely for the economic benefit of Canada in the long term. For example, Canadian Alliance MP Paul Forseth argued in 2001 that international students were valuable because they "can be agents of technology and knowledge transfer," but this was only valuable because it would contribute to growing an "economy that can enhance the social well-being of Canadians" (Forseth, 2001). Similarly, NDP MP Randall Garrison encouraged the Conservative government to recruit more international students in 2011 because they could help "human capacity building" (Garrison, 2011) among Canadians. Specifically, Canada needed to "develop our cultural and not just our trade understanding of Asia," because Asia "was the new power centre of the world" and Canadians needed these skills to "further business opportunities" in the region (Garrison, 2011).

There has been one significant shift in the content of MP policy talk about international students over this era, and at first glance it may appear that this transition represents a new attitude towards students. Starting in the late 1990s, changes to Canadian immigration law have made it possible for international students to become immigrants (Brunner, 2017). MP policy talk about international students has reflected this change, with MPs making occasional references to the idea that international students would make good immigrants to Canada. For example, in 1999 Liberal Minister of Citizenship and Immigration Elinor Caplan suggested that the government should look at international students as a way to bolster immigrant numbers (Caplan, 1999). Her views were ultimately enshrined in the Immigration and Refugee Protection Act (IRPA, 2001), a law she sponsored that created new immigration pathways for international students. However, Caplan was very clear that the reason she wanted to expand access to immigration for international students was because they could "help us build a better and more prosperous life for all Canadians" (Caplan, 1999). Even Caplan's political opponents agreed with this point: In the debate about IRPA Reform MP Leon Benoit echoed Caplan's view when he said "immigration in Canada should benefit Canada. What we want to do is attract the very best of these students and encourage them to stay," especially if they have "some very high level of expertise in a technological area" (Benoit, 2000). Benoit favourably contrasted the efforts to convince international students to become immigrants to the rest of IRPA, explaining that while "the whole idea of generally accepting far more people" to be immigrants was "a real concern," allowing students to apply to become citizens was "positive" (Benoit, 2000). Although discussing international students as immigrants was new, it is clear that MPs continued to view them instrumentally, as extensions of Canada's already existing desires for economic growth. The selection of international students to be immigrants was unproblematic because it fit within the patterns of border imperialism that meant Canada could selectively choose immigrants to serve its needs, while still enforcing exclusionary policies against those who were seen as less desirable (Walia, 2013).

In fact, closer examination of discussions among MPs about international students as potential immigrants shows that rather than a new theme, this new element to policy talk was used by MPs to reinforce definitions of Canadian and non-Canadian as it related to migration more broadly. MPs regularly situated international students as desirable as immigrants because the MPs believed that their studies had transformed them into Canadians. As early as 2000 Benoit lays out this view, explaining that the reason he was so confident in international students as immigrants was because "these students have studied in Canada and have adapted to life in Canada, and maybe, to some extent, the workplace" (Benoit, 2000). Benoit's comments make it clear that he believed international students were likely to be changed by their studies, making them acceptable additions to Canada because they were assimilated into Canadian cultural practices and the Canadian economy. This view is common in MP policy talk about international students as immigrants. As Conservative Minister of Citizenship and Immigration Diane Finley said in 2007, international students are "young, they are motivated and they have a good feel" for Canada-making them ideal candidates to be immigrants (Finley, 2007). Conservative Ted Falk explained that having completed a degree in Canada gave international students the time to "deepen 
their attachment to Canada" before they are considered as permanent residents (Falk, 2014). This attitude was common across the House as well. As Liberal Minister of Immigration, Refugees and Citizenship John McCallum put it in 2016, "international students are some of the best candidates for Canadian citizenship" because "they speak English or French, they received a good education here in Canada, and they know the country" (McCallum, 2016). Given this material, it is clear that as international students became potential immigrants, while the content of MP policy talk changed, the "Canada first" theme that animated their discussion remained intact. In fact, these attitudes are representative of the insider/outsider dichotomy that Bannerji and Sharma both identify as a key element of determining who has access or the right to benefit from membership in the Canadian nation (Bannerji, 2000; Sharma, 2006). Although there was never any evidence provided that studying in Canada did change students, MPs still believed that it was only after being transformed by their studies that international students could move from "foreign-Other" to "us-Canadian" (Sharma, 2006, p. 79) in the rhetoric of MPs.

There is one comment, from Liberal MP Geng Tan, that is distinct from all of the other 273 comments made about international students by MPs between 1984 and 2019. Tan himself had come to Canada as a graduate student, and although he was not the only former international student to speak in Parliament about students (Conservative Chungsen Leung had spoken a few years earlier about the economic value of international students; see Leung, 2013), Tan's experience might have shaped his unique perspective on the value of international students. Although Tan's comment was not exclusively about students-he was actually speaking to mark Lunar New Year in 2016-it is noteworthy for its openness to their intrinsic value as thinkers. Tan explained that "international students enrich our classrooms and their knowledge and skills are welcome in our schools," not because they could be employed to develop Canada's economy or to develop bilateral trade agreements, but because "many Canadians are interested in learning about Asia, but do not have the opportunity to travel outside of Canada" (Tan, 2016). By inviting international students to teach their Canadian neighbours about their traditions, Tan suggested that it would build "strong, diverse communities" (Tan, 2016). Tan's comment stands out as perhaps the only MP statement that speaks pos- itively about international student recruitment and does not attempt to instrumentalize them to some economic end. Yet even Tan still situates international students as outsiders who can serve Canadian interests. He measures their value in a fundamentally different way than any of his colleagues, but ultimately still sees them as a vehicle to advance Canadian interests.

\section{Conclusion}

The desire to change the trajectory of international education, to make it more sustainable and perhaps more just, is laudable and timely. However, if scholars and activists are serious about trying to create a new future for international education, they must account for the underlying assumptions that percolate among key actors. This paper is only a very partial attempt at this, but it demonstrates that MPs views of international students remain rooted in a perspective that views them as foreign-Others who are only valuable to the extent that they advance Canada's interests, especially economically. Until that changes, even modest reform to international student policy in Canada will be difficult to implement at the national level.

\section{Acknowledgements}

Special thanks to Lisa Brunner, Sharon Stein, and the anonymous CJHE reviewers whose generous feedback made this article stronger.

\section{References}

Abdi, A. A. (2012). Decolonizing philosophies of education. http://dx.doi.org/10.1007/978-94-6091-687-8

Alexander, C. (2014, May 13). "Employment." Canada. Parliament. House of Commons. Edited Hansard. 41st Parliament, 2nd Session. Retrieved from LiPaD: The Linked Parliamentary Data Project website: https://www.lipad.ca/full/permalink/4599998/

Alexander, C. (2015, June 1). "Citizenship and Immigration." Canada. Parliament. House of Commons. Edited Hansard. 41st Parliament, 2nd Session. Retrieved from LiPaD: The Linked Parliamentary Data Project website: https://www.lipad.ca/full/permalink/4641831/ 
Aman, R. (2018). Decolonising intercultural education: Colonial differences, the geopolitics of knowledge, and inter-epistemic dialogue. Routledge.

Angulo, A. J. (2012). Empire and education: A history of greed and goodwill from the War of 1898 to the War on Terror. Palgrave Macmillan. https://doi. org/10.1057/9781137024534

Association of Canadian Deans of Education. (2014). Accord on the internationalization of education. http://www.csse-scee.ca/docs/acde/Accord Internationalization_EN.pdf

Bannerji, H. (1995). Thinking through essays on feminism, Marxism and anti-racism. Women's Press.

Bannerji, H. (1996). On the dark side of the nation: Politics of multiculturalism and the state of "Canada." Journal of Canadian Studies, 31(3), 103-128. https://doi.org/10.3138/jcs.31.3.103

Bannerji, H. (2000). The dark side of the nation essays on multiculturalism, nationalism and gender. Canadian Scholars' Press.

Beck, K. (2012). Globalization/s: Reproduction and resistance in the internationalization of higher education. Canadian Journal of Education/Revue Canadienne de l'éducation, 35(3), 133-148. https://journals.sfu.ca/cje/index.php/cje-rce/article/ view/1077

Beelen, K., Thijm, T. A., Cochrane, C., Halvemaan, K., Hirst, G., Kimmins, M., Lijbrink, S., Marx, M., Naderi, N., Rheault, L., Polyanovsky, R., \& Whyte, T. (2017). Digitization of the Canadian Parliamentary Debates. Canadian Journal of Political Science, 50(3), 849-864. https://doi.org/10.1017/ S0008423916001165

Benoit, L. (2000, May 1). "Immigration and Refugee Protection Act." Canada. Parliament. House of Commons. Edited Hansard. 36th Parliament, 2nd Session. Retrieved from LiPaD: The Linked Parliamentary Data Project website: https://www.lipad.cal full/permalink/4157624/

Brewer, C. A. (2014). Historicizing in critical policy analysis: The production of cultural histories and microhistories. International Journal of Qualitative Studies in Education, 27(3), 273-288. https://doi.org

\section{/10.1080/09518398.2012.759297}

Brownlee, J., Hurl, C., \& Walby, K. (Eds.). (2018). Corporatizing Canada: Making business out of public service. Between the Lines.

Brunner, L. R. (2017). Higher educational institutions as emerging immigrant selection actors: A history of British Columbia's retention of international graduates, 2001-2016. Policy Reviews in Higher Education, 1(1), 22-41. https://doi.org/10.1080/23322969. 2016.1243016

Canadian Bureau for International Education. (2014). Internationalization statement of principles for Canadian educational institutions. http://cbie.cal our-network/become-a-member/internationalization-statement-of-principles-for-canadian-educational-institutions/

Canadian Bureau for International Education. (2019). International students in Canada. https://cbie.ca/ infographic/

Cannan, R. (2014, Oct. 28). "Canada-Korea Economic Growth and Prosperity Act." Canada. Parliament. House of Commons. Edited Hansard. 41st Parliament, 2nd Session. Retrieved from LiPaD: The Linked Parliamentary Data Project website: https:/l www.lipad.ca/full/permalink/4616004/

Caplan, E. (1999, Nov. 5). "Oral question period: Immigration." Canada. Parliament. House of Commons. Edited Hansard. 36th Parliament, 2nd Session. Retrieved from LiPaD: The Linked Parliamentary Data Project website: https://www.lipad.ca/full/permalink/4133489/

Chen, L., \& Chen, T.-L. (2018). International students' conceptions of the sustainable internationalization of business education in Taiwan. Sustainability, 10(11), 4292. https://doi.org/10.3390/su10114292

Clark, C. J. (1986, Dec. 4). "Routine Proceedings: Canada's International Relations." Canada. Parliament. House of Commons. Edited Hansard. 33rd Parliament, 2nd Session. Retrieved from LiPaD: The Linked Parliamentary Data Project website: https:// www.lipad.ca/full/permalink/3633627/

Clarke, A. (2018, Nov. 6). "Budget Implementation Act, 2018, No. 2." Canada. Parliament. House of 
Commons. Edited Hansard. 42nd Parliament, 1st Session. Retrieved from LiPaD: The Linked Parliamentary Data Project website: https://www.lipad.cal full/permalink/4760156/

Coderre, D. (2002, Oct. 2). "Speech from the Throne." Canada. Parliament. House of Commons. Edited Hansard. 37th Parliament, 2nd Session. Retrieved from LiPaD: The Linked Parliamentary Data Project website: https://www.lipad.ca/full/permalink/4224687!

Coderre, D. (2003, Sept. 22). "Immigration." Canada. Parliament. House of Commons. Edited Hansard. 37th Parliament, 2nd Session. Retrieved from LiPaD: The Linked Parliamentary Data Project website: https://www.lipad.ca/full/permalink/4256979/

Coloma, R. S. (2009). "Destiny has thrown the Negro and the Filipino under the tutelage of America": Race and curriculum in the Age of Empire. Curriculum Inquiry, 39(4), 495-519. https://doi.org/10.1111/ j.1467-873X.2009.00454.X

DeCourcey, M. (2016a, March 10). "Immigration, Refugees and Citizenship." Canada. Parliament. House of Commons. Edited Hansard. 42nd Parliament, 1st Session. Retrieved from LiPaD: The Linked Parliamentary Data Project website: https://www.lipad.cal full/permalink/4654824/

DeCourcey, M. (2016b, March 10). "Citizenship Act." Canada. Parliament. House of Commons. Edited Hansard. 42nd Parliament, 1st Session. Retrieved from LiPaD: The Linked Parliamentary Data Project website: https://www.lipad.ca/full/permalink/4655107/

Diem, S., Young, M. D., Welton, A. D., Mansfield, K. C., \& Lee, P.-L. (2014). The intellectual landscape of critical policy analysis. International Journal of Qualitative Studies in Education, 27(9), 1068-1090. https://doi.org/10.1080/09518398.2014.916007

Epp, K. (1994, Nov. 3). “Credentials." Canada. Parliament. House of Commons. Edited Hansard. 35th Parliament, 1st Session. Retrieved from LiPaD: The Linked Parliamentary Data Project website: https:ll www.lipad.ca/full/permalink/3978869/

Falk, T. (2014, May 28). “Strengthening Canadian
Citizenship Act." Canada. Parliament. House of Commons. Edited Hansard. 41st Parliament, 2nd Session. Retrieved from LiPaD: The Linked Parliamentary Data Project website: https://www.lipad.cal full/permalink/4602220/

Finley, D. (2007, Feb. 22). "Business of Supply." Canada. Parliament. House of Commons. Edited Hansard. 39th Parliament, 1st Session. Retrieved from LiPaD: The Linked Parliamentary Data Project website: https://www.lipad.ca/full/permalink/4353867/

Folco, R. (2006, May 8). "Financial Statement of Minister of Finance." Canada. Parliament. House of Commons. Edited Hansard. 39th Parliament, 1st Session. Retrieved from LiPaD: The Linked Parliamentary Data Project website: https://www.lipad.ca/ full/permalink/4326356/

Forseth, P. (2001, Feb. 27). "Immigration and Refugee Protection Act." Canada. Parliament. House of Commons. Edited Hansard. 37th Parliament, 1st Session. Retrieved from LiPaD: The Linked Parliamentary Data Project website: https://www.lipad.cal full/permalink/4175663/

Freeland, C. (2016, Feb. 25). "International trade." Canada. Parliament. House of Commons. Edited Hansard. 42nd Parliament, 1st Session. Retrieved from LiPaD: The Linked Parliamentary Data Project website: https://www.lipad.ca/full/permalink/4653522/

Gale, T. (2001). Critical policy sociology: Historiography, archaeology and genealogy as methods of policy analysis. Journal of Education Policy, 16(5), 379393. https://doi.org/10.1080/02680930110071002

Garrison, R. (2011, Oct. 6). "International trade." Canada. Parliament. House of Commons. Edited Hansard. 41st Parliament, 1st Session. Retrieved from LiPaD: The Linked Parliamentary Data Project website: https://www.lipad.ca/full/permalink/4494552/

Government of Canada. (2014). Canada's international education strategy: Harnessing our knowledge advantage to drive innovation and prosperity. http:ll international.gc.ca/global-markets-marches-mondiaux/assets/pdfs/overview-apercu-eng.pdf

Harney, R. F. (1988). "So great a heritage as ours": Immigration and the survival of the Canadian polity. 
Daedalus, 117(4), 51-97. http://www.jstor.org/stable/20025197

Harvey, D. (2005). A brief history of neoliberalism. Oxford University Press.

Holdaway, E. A., Bryant, W. M., \& Allan, W. H. (1988). International university students in Canada: Obtaining the information needed for policy making. The Canadian Journal of Higher Education, 18(3), 17. https://journals.sfu.ca/cihe/index.php/cihe/article/ view/183043

Hudzik, J. K. (2014). Comprehensive Internationalization: Institutional pathways to success (1st ed.). Routledge. https://doi.org/10.4324/9781315771885

Hussen, A. (2019, May 13). "Immigration, Refugees and Citizenship." Canada. Parliament. House of Commons. Edited Hansard. 42nd Parliament, 1st Session. Retrieved from LiPaD: The Linked Parliamentary Data Project website: https://www.lipad.ca/ full/permalink/4779147/

Ilieva, R., Beck, K., \& Waterstone, B. (2014). Towards sustainable internationalisation of higher education. Higher Education, 68, 875-889. https://doi. org/10.1007/s10734-014-9749-6

Immigration and Refugee Protection Act (IRPA). (2001, c. 27). Retrieved from the Justice Laws website: https://laws.justice.gc.ca/eng/acts/i-2.5/

Jaffer, R. (2006, May 12). "Budget Implementation Act, 2006." Canada. Parliament. House of Commons. Edited Hansard. 39th Parliament, 1st Session. Retrieved from LiPaD: The Linked Parliamentary Data Project website: https://www.lipad.ca/full/permalink/4327473/

Jang, E. (2017). Sustainable internationalization in South Korean higher education: Languages and cultures in a foreign professor's course. Higher Education, 73(5), 673-689. http://doi.org/10.1007/ s10734-016-9987-x

Johnstone, M., \& Lee, E. (2014). Branded: International education and 21st-century Canadian immigration, education policy, and the welfare state. International Social Work, 57(3), 209-221. https://doi. org/10.1177/0020872813508572
Johnstone, M., \& Lee, E. (2017). Canada and the global rush for international students: Reifying a neo-imperial order of Western dominance in the knowledge economy era. Critical Sociology, 43(7-8), 10631078. https://doi.org/10.1177/0896920516654554

Kang, D. S. (2019, May 13). "Immigration, Refugees and Citizenship." Canada. Parliament. House of Commons. Edited Hansard. 42nd Parliament, 1st Session. Retrieved from LiPaD: The Linked Parliamentary Data Project website: https://www.lipad.cal full/permalink/4779146/

Kenney, J. (2012, May 4). "Oral Questions: Immigration.” Canada. Parliament. House of Commons. Edited Hansard. 41st Parliament, 1st Session. Retrieved from LiPaD: The Linked Parliamentary Data Project website: https://www.lipad.ca/full/permalink/4521767!

Kleinberg, E., Scott, J. W., \& Wilder, G. (2020). Theses on theory and history. History of the Present: $A$ Journal of Critical History, 10(1), 157-165. https:/l doi.org/10.1215/21599785-8221515

Knight, J. (2015). Updated definition of internationalization. International Higher Education, (33). http:ll ejournals.bc.edu/ojs/index.php/ihe/article/viewFile/7391/6588

Komarnicki, E. (2007, Feb. 22). "Business of Supply." Canada. Parliament. House of Commons. Edited Hansard. 39th Parliament, 1st Session. Retrieved from LiPaD: The Linked Parliamentary Data Project website: https://www.lipad.ca/full/permalink/4353661/

Leung, C. (2013, April 18). "Business of Supply." Canada. Parliament. House of Commons. Edited Hansard. 41st Parliament, 1st Session. Retrieved from LiPaD: The Linked Parliamentary Data Project website: https://www.lipad.ca/full/permalink/4561273/

Ludwig, K. (2017, May 17). "Foreign Affairs, Trade and Development - Main estimates, 2016-17." Canada. Parliament. House of Commons. Edited Hansard. 42nd Parliament, 1st Session. Retrieved from LiPaD: The Linked Parliamentary Data Project website: https://www.lipad.ca/full/permalink/4710048/

Malone, A.J. (1990, June 11). “Government Expenditures 
Restraint Act - Measure to Amend." Canada. Parliament. House of Commons. Edited Hansard. 34th Parliament, 2nd Session. Retrieved from LiPaD: The Linked Parliamentary Data Project website: https://www.lipad.ca/full/permalink/3833997/

Marchi, S. (1987, Sept. 28). "Immigration Act, 1976 Measure to Amend." Canada. Parliament. House of Commons. Edited Hansard. 33rd Parliament, 2nd Session. Retrieved from LiPaD: The Linked Parliamentary Data Project website: https://www.lipad.cal full/permalink/3692064/

McBride, S. (2005). Paradigm shift: Globalization and the Canadian state (2nd ed.). Fernwood Publishing.

McCallum, J. (2016, March 9). "Immigration, Refugees and Citizenship." Canada. Parliament. House of Commons. Edited Hansard. 42nd Parliament, 1st Session. Retrieved from LiPaD: The Linked Parliamentary Data Project website: https://www.lipad.cal full/permalink/4654644/

McCartney, D. M. (2016). Inventing international students: Exploring discourses in international student policy talk, 1945-75. Historical Studies in Education/Revue d'histoire de l'éducation, 28(2), 1-27. https://historicalstudiesineducation.ca/index.php/ edu hse-rhe/article/view/4457/4727

Minna, M. (2008, April. 4). "Budget Implementation Act, 2008." Canada. Parliament. House of Commons. Edited Hansard. 39th Parliament, 2nd Session. Retrieved from LiPaD: The Linked Parliamentary Data Project website: https://www.lipad.ca/full/permalink/4391262/

Pepin, J. L. (1984, June 1). "Asia-Pacific Foundation of Canada Act to Establish." Canada. Parliament. House of Commons. Edited Hansard. 32nd Parliament, 2nd Session. Retrieved from LiPaD: The Linked Parliamentary Data Project website: https:/l www.lipad.ca/full/permalink/3484764/

Peschisolido, J. (2003, May 26). "Supply." Canada. Parliament. House of Commons. Edited Hansard. 37th Parliament, 2nd Session. Retrieved from LiPaD: The Linked Parliamentary Data Project website: https://www.lipad.ca/full/permalink/4251714/

Price, D. (2000, March 23). "Citizenship of Canada
Act." Canada. Parliament. House of Commons. Edited Hansard. 36th Parliament, 2nd Session. Retrieved from LiPaD: The Linked Parliamentary Data Project website: https://www.lipad.ca/full/permalink/4153671/

Rompkey, B. (1987, April 27). “Private members' business - Motions education access by international students to post-secondary institutions." Canada. Parliament. House of Commons. Edited Hansard. 33rd Parliament, 2nd Session. Retrieved from LiPaD: The Linked Parliamentary Data Project website: https://www.lipad.ca/full/permalink/3660403/

Saxton, A. (2012, Feb. 29). "Southeast Asia." Canada. Parliament. House of Commons. Edited Hansard. 41st Parliament, 1st Session. Retrieved from LiPaD: The Linked Parliamentary Data Project website: https://www.lipad.ca/full/permalink/4512331/

Serré, B. (1994, April 25). "New Liskeard College of Agricultural Technology." Canada. Parliament. House of Commons. Edited Hansard. 35th Parliament, 1st Session. Retrieved from LiPaD: The Linked Parliamentary Data Project website: https://www.lipad.ca/ full/permalink/3964216/

Sharma, N. (2006). Home economics: Nationalism and the making of "migrant workers" in Canada. University of Toronto Press.

Stein, S. (2017a). Internationalization for an uncertain future: Tensions, paradoxes, and possibilities. The Review of Higher Education, 41(1), 3-32. https:/l doi.org/10.1353//rhe.2017.0031

Stein, S. (2017b). National exceptionalism in the "EduCanada" brand: Unpacking the ethics of internationalization marketing in Canada. Discourse: Studies in the Cultural Politics of Education, 39(3), 1-17. https://doi.org/10.1080/01596306.2016.1276884

Tan, G. (2016, June 1). “Private Members' Business: Spring Festival." Canada. Parliament. House of Commons. Edited Hansard. 42nd Parliament, 1st Session. Retrieved from LiPaD: The Linked Parliamentary Data Project website: https://www.lipad.cal full/permalink/4675166/

Teeple, G. (2000). Globalization and the decline of social reform: Into the twenty-first century. Garamond Press. 
Telegdi, A. (2008, June 2). "Budget Implementation Act, 2008." Canada. Parliament. House of Commons. Edited Hansard. 39th Parliament, 2nd Session. Retrieved from LiPaD: The Linked Parliamentary Data Project website: https://www.lipad.ca/full/permalink/4399720/

Trilokekar, R. D., \& El Masri, A. (2016). Canada's international education strategy: Implications of a new policy landscape for synergy between government policy and institutional strategy. Higher Education Policy, 29(4), 539-563. https://doi-org/10.1057/ s41307-016-0017-5

Tyack, D. B., \& Cuban, L. (1995). Tinkering toward utopia: A century of public school reform. Harvard University Press.

Walia, H. (2013). Undoing border imperialism. AK Press.

Willinsky, J. (1998). Learning to divide the world: Education at empire's end. University of Minnesota Press.

\section{Contact Information}

Dale M. McCartney

dale.mccartney@ufv.ca 